\title{
Validity of J-Curve for Turkey and Its Main External Trade Partners: An Application of a Panel Data Approach
}

\author{
Mehmet Çăgrı GÖZEN (https://orcid.org/0000-0001-6493-9592), Kocaeli University, Turkey; \\ cagri.gozen@gmail.com
}

Fikriye Ceren BOSTANCI (https://orcid.org/0000-0001-8291-062X), Kocaeli University, Turkey; ceren.bostanci@kocaeli.edu.tr

\section{Türkiye ve Ana Ticaret Partnerleri için J Eğrisinin Geçerliliğinin Analizi: Panel Veri Yaklaşımı Uygulaması}

\begin{abstract}
External trade cannot create the expected result for some countries due to their economic structures or policies. Economies could encounter severe foreign trade deficits and the risk of an economic crisis. Thus, researchers and policymakers analyse the dynamics of countries' external trade balances. Turkey's persistent current account deficit is one of the most significant macroeconomic problems. Turkey depreciated the Turkish Lira against foreign currencies to reduce its foreign trade deficit in the past. Using panel data analysis, the current study tests the J-curve for Turkey and its six main foreign trade partner countries - Russia, USA, Germany, UK, Italy, and China. Results do not support the validity of the J-curve hypothesis in the long run. Test results analysing the short-run indicate that the whole panel is statistically insignificant.
\end{abstract}

Keywords

: J-Curve, External Trade Deficits, Westerlund Panel Cointegration Analysis, DOLS Method, DCCE Model.

JEL Classification Codes : $\quad$ C33, F10.

\section{$\ddot{\mathbf{O} z}$}

Dış ticaret ekonomik yapılarından veya uyguladıkları ekonomi politikalarından dolayı bazı ülkeler için arzu edilen sonuçlar doğurmaz ve ülkeler bundan dolayı önemli dış ticaret açıkları veya ekonomik krizlerle yüz yüze gelebilir. Bu yüzden araştırmacılar ve politika yapıcılar ülkelerin dış ticaret dengelerinin dinamiklerini analiz ederler. Türkiye'nin kronik cari işlemler açığı en önemli makroekonomik sorunlarından biridir ve geçmişte Türkiye parasının değerini düşürerek dış ticaret açığını azaltmaya çalışmıştır. Bu çalışmada Türkiye ve onun 6 ana diş ticaret partneri için - Rusya, ABD, Almanya, Birleşik Krallık, İtalya ve Çin- J eğrisi hipotezinin geçerliliği sınanmıştır. Kısa dönemi analiz eden test sonuçlarına göre bütün panel istatistiksel olarak anlamsız çıkmıştır. 
Gözen, M.Ç. \& F.C. Bostancı (2021), "Validity of J-Curve for Turkey and Its Main External

Trade Partners: An Application of a Panel Data Approach", Sosyoekonomi, 29(50), 149-168.

\section{Introduction}

Structural changes in the world economy make it essential for the countries to harmonize their policies with global economic policies appropriately. Thus, most of the countries, including Turkey, get involved in free foreign trade policy. Memberships of India and China to the World Trade Organization and customs union agreement between the European Union and Turkey could be cited as attempts of countries to be part of an international economic system. As a result of free international trade, economies are affected more by the emerging developments regarding exchange rates and foreign trade policies. Hence, due to capital flows reaching higher volumes and growing international trade, any country's negative economic or political condition could negatively impact other countries. It even sometimes gives rise to significant political tensions. Recently, currency wars between the USA and China could be given an embodiment of this situation. Currency wars are continuing to happen. The current situation will negatively affect the global economy, resulting in economic losses for countries in anticipation of policymakers.

Countries could struggle to raise competitiveness by devaluating their currencies to remove their deficits or take preventive precautions under the circumstances mentioned above. Adopted exchange rate policies have an effect not only upon the balance of payments but also upon macroeconomic variables. The theory states that domestic products will be cheaper for foreign customers when the exchange rate increases, increasing foreign demand. Demand increase has a positive impact on a country whose currency depreciates. Besides, import goods will be relatively expensive due to increased exchange rates, and domestic consumers must pay more to buy them. This causes a decrease in demand for imported goods. Therefore, countries try to enhance their competitiveness in international trade occasionally.

In consequence of devaluation made by related policymakers in the countries implying fixed exchange rates or by increasing the exchange rates on the market in the countries applying free exchange rate system, the relative price of tradable goods will change. This also changes the import and export. Effects of these changes are dependent on the elasticity of demand and supply of tradable goods. Marshall (1923) and Lerner (1944) specify that the summation of demand and supply elasticities should be more significant than one so that devaluation can give desirable results. This statement, known as the MarshallLerner condition, explains demands of export and import goods depending on price elasticities could remove external trade deficits. This condition is shown as $e_{m}+e_{x} \geq 1$. Here, $\mathrm{e}_{\mathrm{m}}$ and $\mathrm{e}_{\mathrm{x}}$ represent domestic demand elasticities of import goods and export goods, respectively. The more their summation is above 1, the more trade deficit is removed associated with changes in real exchange rates (Köseyaylaoğlu \& Karataşl1, 2018: 834).

Analysing the competition power in foreign trade gained from exchange rate policies becomes significant. If it is looked at from the viewpoint of competition power, short-term and long-term effects of devaluation emphasize the price factor in determining competition power. To see the efficiency of the price factor, as specified in the Marshall-Lerner 
condition, it should be checked whether changing exchange rates in consequence of devaluation generates worsening trade balance. On the other hand, the foreign trade balance will recover long-term, and J-curve will arise. According to results obtained, competition based on price or non-price factors produces more effective, decisive results.

The J-curve phenomenon explains how to trade balance responds to devaluation. Magee (1973), introducing this phenomenon, asserts that devaluations cannot generate expected impact at first due to reasons such as production, contracts, or deliveries. External trade deficit becomes higher at the beginning of devaluation, in the following process, external trade deficit decreases. Volume and price cause this situation to occur. Short-time elasticities are low since import and export contracts are made in advance, and thus, exchange rate changes do not change the external trade volume. Changes in exchange rates show their impacts in the long term. However, the price effect instantly shows its impact on external trade. After the devaluation, the price of export goods abroad decreases, and the price of import goods in terms of national currency increases. This situation, at first, creates more trade deficits. But new contracts are made with the adjustment of importer and exporter to the new exchange rate level. In this case, demand for import goods decreases while demand for export goods increases. In the long run, the external trade deficit begins to close. This situation is called the $\mathrm{J}$-curve effect. The $\mathrm{J}$-curve approach points out that there are price rigidities in the short run and domestic currency depreciation deteriorates the trade balance. After the short-run response worsening the trade balance deficit, depreciation improves the external trade balance in the long run, and the external trade balance gap begins to close.

As shown in Figure 1, J-curve is a trendline starting with a dramatic increase in loss followed by a long-term gain immediately afterward. Following the depreciation of its currency, since import goods become more expensive and export goods are cheaper country's current account deficit increases. That is, the balance of payment worsens initially. After that, as export goods are cheaper, more export goods are sold to the foreign countries, and less import goods are bought from the other countries because they are more expensive. Thus, the recovery process for trade balance starts, and the current account deficit decreases, or the current account surplus happens in the long term. Due to the pre-existing contracts, the total import volume will increase, and export volume will remain unchanged. In addition, since consumers need time to search for cheaper alternative products, demand for the more expensive import goods remains price inelastic. These are why import prices rise, and the trade balance worsens in the short run because of depreciation. In the short run, as there is a lag in demand for import goods, a drop followed by the lag arises in import volume. In the long run, consumers stop demanding expensive import goods, and this, along with the increase in export volume, causes either a smaller deficit or a more significant surplus. The expected outcome from domestic currency depreciation over the longer term is to have a better current account balance because domestic consumers prefer domestic goods more than imported goods. Equally, foreign consumers are now more willing to prefer the products imported to their country, depreciating its currency because they are cheaper. 


\section{Figure: 1}

J-Curve

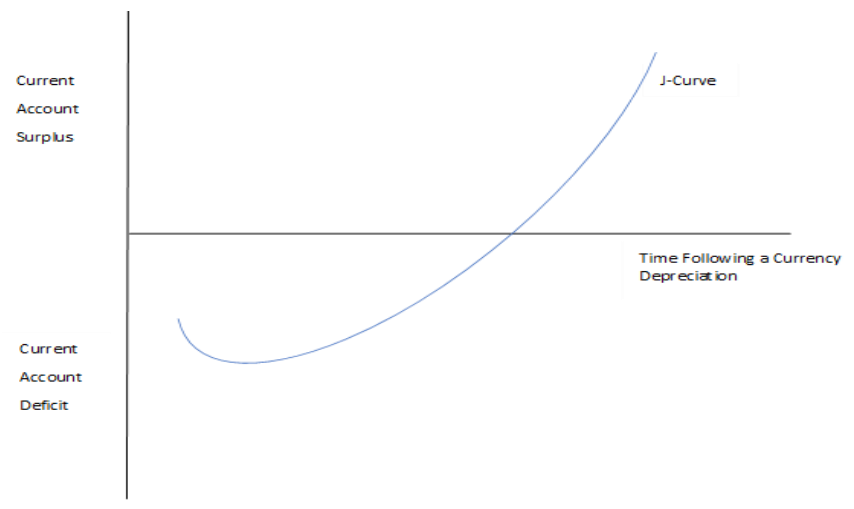

Turkey has a chronicle balance of payments problem. Turkish Lira has been devaluated many times to solve this problem, but the effects of these devaluations were limited. It gives better results to include the main trade partners of Turkey into the model to detect the validity of the J-curve analysis. In the literature, the validity of the J-curve is evaluated just for Turkey or in a group not including all main trade partners of Turkey. Some studies examine the validity of J-curve analysis for Turkey and its trade partners, but they do not use aggregate data. This study differs from the related literature on the J-curve effect in Turkey on three accounts. Firstly, unlike other studies, we analyse Turkey and its main trade partners by using aggregate data. Secondly, DOLS long-term and DCCE short-term estimators whose short- and long-term power is proven by Monte Carlo experiments are utilized to estimate parameters. Previous studies concerning the J-curve hypothesis for Turkey did not apply these estimators. Finally, by analysing the validity of J-curve as a group and different country, whether they exhibit the same behaviour as an individual country and a panel group could be seen. In this way, more consistent and stronger evidence could be given to detect the validity of the J-curve.

The trade balance is dependent on its leading trade partners' trade balance and economic condition. Thus, the validity of the J-curve for a country should be analysed together with its main trade partners. Despite a lot of studies in this literature, many of the researchers preferred time series analysis methods. Due to the economic dependency between the countries, this cross-sectional dependency could be included in the model via panel data methods, and the effects of the dependency on test results can be represented. On the other hand, short- and long-term parameter estimations should be conducted. Therefore, panel time-series techniques are preferred. Aggregate, bilateral and sectoral data are used in the j-curve analysis. Aggregate data is preferred in this study, although the models used to use three kinds of data. By using aggregate data, countries in the panel, including Turkey, could be analysed as a group, unlike bilateral data. As a group, behaviours of countries in the panel could be evaluated economically when aggregate data is used. Apart from the J- 
curve literature for Turkey, findings from this study are considered complementary to the literature in showing the invalidity of J-curve both for all countries individually and as a group. These results give stronger and more valid findings of Turkey and its main trade partners. Devaluation of the domestic currency will not give the desired result.

In this study, the validity of the J-curve hypothesis for Turkey and its main trading partners is examined by utilizing Westerlund Panel Cointegration Test, Dynamic Ordinary Least Squares Mean Group Estimator methods, and annual data covering the period over 1995-2018 is employed. Preliminary tests support the suitability of methods employed in this study, contributing to the originality of this paper. The superiority of these methods, in comparison with other methods, is emphasized by different researchers. These comparisons are mentioned in the data and methodology section in more detail. The paper will be organized as follows. Literature is presented in the following section. After that methodology and data section is introduced. Following this, we present the test results section. The Paper will be finished with a conclusion section.

\section{Literature Review}

Since this study is about Turkey and its main trading partners, a broad part of the literature review is about the validity of the J-curve for Turkey. It is seen from the related literature for both Turkey and other countries that the validity of this approach has been tested by using different variables having data with various frequencies and utilizing various econometric methods. Time series analysis methods, especially for Turkey, are mainly preferred in empirical studies in the J-curve literature. A great many studies testing this phenomenon use single and multivariate cointegration methods. These empirical studies have two major trends, one of which is the aggregate trade balance approach. The other studies employ a bilateral trade balance approach. Time series of a country utilized in the analysis are influenced not only by the country's dynamics but also by the dynamics of countries with which the country has intense trade ties. Thus, this study aims to contribute to the related literature by using panel data analysis, which allows the effects of main trading partners' dynamics on Turkey.

Rose (1990) employs a three-stage least square method for testing the J-curve for 30 countries, including Turkey, for the period 1970-1988. Empirical results indicate that there is no substantial effect of real exchange rates on the trade balance. Using quarterly data from 1969 to 1993 , Brada et al. (1997) examine the reaction of the trade balance of Turkey to the devaluation by employing time series methods. They conclude that real exchange rates influence trade balance in the long run and trade liberalization during the 1980s. Yazici and Klasra (2010) investigated the response of devaluation on the Turkish economy's trade balance by employing the Almon lag technique, cointegration method, and impulse response function for the data covering 1986 to 1998. J-curve is not valid for manufacturing and mining industries. 
Gözen, M.Ç. \& F.C. Bostancı (2021), "Validity of J-Curve for Turkey and Its Main External

Trade Partners: An Application of a Panel Data Approach", Sosyoekonomi, 29(50), 149-168.

Elmas and Elmas (2019), in their study, investigated the validity of the J-curve in the Bandırma district by employing cointegration, causality, and Wilcoxon Sign Rank Test. In this study for the period of 1996-2015, it was found that there is a cointegration relationship between the foreign trade balance and the real exchange rate, and the real exchange rate is the cause of the Granger foreign trade balance. The researchers, who stated that the cointegration analysis did not give much information about the J-curve, continued with the Wilcoxon Sign Rank Test. The researchers concluded that the J-curve is valid in the Bandırma district according to the relevant test results. Akkaya (2018) examined whether the J-curve is valid with the bound test approach in Turkey and Turkey's 13 foreign trade partners (Belgium, Canada, China, Finland, France, Germany, Italy, Netherlands, Portugal, Spain, Sweden, UK, and the USA). According to the results, after the devaluation of the Turkish Lira, it is concluded that the J-curve is not valid in Belgium, Canada, Finland, and the UK. France, Germany, and Holland are positively affected by this loss. Y1lmaz et al. (2017) examined the short-term, and long-term relationship between the foreign trade deficit, the real exchange rates, and the Gross Domestic Product (GDP) variables with the ARDL bound test approach to investigate the validity of the J-curve hypothesis in Turkey. According to the analysis results, it was concluded that the real exchange rates did not statistically affect the foreign trade deficit. Authors interpreting this situation mention foreign trade structure is becoming more and more liberated and point out the nonexistence of J-curve in the corresponding period in Turkey.

The relationship between real exchange rate, export price index, and import price index for Turkey is analysed by Hepaktan (2016) via Maki Cointegration Analysis, allowing multiple structural breaks with the help of quarterly data covering the period 1990-2016. Test results do not show long-term cointegration relation among the series. Findings from the Toda-Yamamato causality test point out a unidirectional causality from two variables to real exchange rates. Kemeç and Kösekahyaoğlu (2015) analyse the validity of the Marshall Lerner condition and J-curve for Turkey over 1997-2013. The VAR model and Granger causality test are utilized using quarterly data, supporting the Marshall Lerner condition and J-curve hypothesis. Bal and Demiral (2012) examine bilateral trade of Turkey with Germany over the period 2002-2012 by using monthly data. Evidence obtained from the vector error correction model and causality test reveal Marshall Lerner condition does not hold in the short-run since the elasticity of exchange rates in the trade balance is positive in the long run and negative in the short-run. Findings from this study support the J-curve adjustment process. In this study using quarterly data over 1985-2005, Halicioglu (2008) empirically investigates the J-curve adjustment process of Turkey and its 13 main trading partners. Bounds cointegration testing and error correction model are utilized, and findings indicate no evidence for J-curve in the short run. At the same time, the trade balance of Turkey with the UK and the U.S. is positively affected by real depreciation in the long run. Akbostanc1 (2004) investigated the J-curve effect in Turkey for the 1987-2000 period by VECM and impulse-response function. According to the study results, although the long-term relationship between variables supports the J-curve effect, the short-term relationship does not support this effect. 
Gözen, M.Ç. \& F.C. Bostanc1 (2021), "Validity of J-Curve for Turkey and Its Main External Trade Partners: An Application of a Panel Data Approach", Sosyoekonomi, 29(50), 149-168.

Rose and Yellen (1989) analysed the J-curve between the US and its six main trading partners and started the bilateral trade balance trends. They used the data covering for 19601985 and employed a cointegration test. It is concluded from the test results data does not support the convincing evidence of the existence of J-curve for both aggregate and bilateral approaches. Moffett (1989) examines the J-curve for the US over the period 1967-1987. Estimation results for the long-run trade balance imply a sine wave. An empirical evaluation for the import sector is consistent with the J-curve hypothesis. However, although export earnings increase due to dollar devaluation, this rise is insufficient to cover the increasing import expenditures. Backus et al. (1994) test J-curve effect for 11 developed countries, including the US, United Kingdom, Germany, and Italy, for the 1955-1990 period. Their findings show that net export and trade data are highly autocorrelated, and the crosscorrelation function has an asymmetrical S shape. In their study, Demirden and Pastine (1995) employ the OLS method and its variations to analyse the J-curve hypothesis using US data covering 1978-1993. Signs of the variables' coefficients do not support the evidence of J-curve. Ali and Anwar (2017) employ the dynamic stochastic general equilibrium model to explain the J-curve phenomenon. Their findings mention an increase in the intensity of the J-curve effect with the cost channel of monetary policy.

To determine the nonlinear nexus between real exchange rates and trade balance for China and its 21 trading partners, Bahmani-Oskooee et al. (2018) employ NARDL methodology using quarterly data from 2000-2015. Their findings indicate the adjustment asymmetry for 11 partners in the short and long run, and asymmetric effects exist in cases of five partners. Nusair (2017) utilizes linear and nonlinear ARDL (NARDL) model using quarterly data to examine the existence J-curve hypothesis for 16 European transition economies. The results of the linear ARDL model do not support the J-curve hypothesis, while the NARDL model shows evidence for the validity of the J-curve hypothesis in 12 economies. By using quarterly bilateral data over the period 1971-2013, Bahmani-Oskooee and Fariditavana (2016) analyse the existence of J-curve for the US and its major trading partners (Canada, France, Germany, Italy, Japan, and the UK). NARDL approach is applied to determine the J-curve effect. The introduction of a nonlinear adjustment process supports more evidence favouring the J-curve than the linear model. In their study, Bahmani-Oskooee and Fariditavana (2015) search for evidence of the J-curve by introducing non-linearity for 1973-2014. For Canada, the USA, China, and Japan, trade balance models are estimated using linear and nonlinear ARDL, and quarterly data is analysed. The linear process supports the validity of the J-curve for the USA, while evidence from the nonlinear process shows that the J-curve is valid for China and the USA.

For China and its 18 trading partners, Wang et al. (2012) investigate the J-curve hypothesis in the short run and the trade balance effect of the real exchange rate over the period 2005-2008 using monthly data. A fully modified OLS for heterogeneous cointegrated panel (panel FMOLS) model and panel error correction model (panel ECM) is utilized to detect the validity of the J-curve hypothesis. Their results reveal the fact that RMB is not of long-run effect on the trade balance of China. Bahmani-Oskooee and Hajilee (2012) investigated the trade balance response of industries in case of depreciation of Euro between 
Germany and the U.S. According to results, using annual data over the period 1962-2009 and bounds testing approach, 91 industries respond to exchange rate fluctuations in the shortrun, but J-curve is valid only for eight industries. Evidence also supports improvement in the trade balance for 31 industries in the event of currency depreciation. Hsing and Sergi (2010) examined the validity of the J-curve for the 1980-2007 period in Australia, Canada, New Zealand, and the UK by vector error correction model (VECM) and generalized impact response function. While evidence of the J-curve exists in New Zealand, it is concluded that it is not valid in Australia, Canada, and the UK. Bahmani-Oskooee and Kutan (2009) test the J-curve hypothesis for 11 east European countries. This study uses monthly data covers for 1990-2005 and uses the bound test approach and error correction model. Findings support the J-curve hypothesis in Bulgaria, Croatia, and Russia. Bahmani-Oskooee and Wang (2006), in their study, highlighted that the use of aggregate trade data in previous studies investigating the existence of the J-curve in China yielded complex results and decomposed the data for China and 13 trading partners. They analysed the appropriate data for the period 1983-2002 by the ARDL approach. As a result of the study, no positive results were found in the direction of the J-curve.

\section{Data and Methodology}

In contrast to many studies in related literature for Turkey, six main trade partners of Turkey are included in panel data analysis to consider Turkey's internal dynamics and consider the effects of other countries' internal dynamics on the existence of J-curve for Turkey. All countries' data are available from 1995 to 2018 . Annual data covering the period 1995-2018 is applied. Export Value Index/Import Value Index variable is employed as the dependent variable and denoted as bop. Variables are obtained from World Bank Statistics. exc variable describing real exchange rates is used as the independent variable for Turkey, Russia, USA, Germany, UK, Italy, and China. STATA 14.0 software is used to obtain results.

Studies conducted with panel data analysis examine the common dynamics of unit gathering for various reasons, while research conducted with time series analysis investigates dynamics of one unit in time. At this point, panel data analysis is often preferred in international economics literature to analyse the countries economically interdependently. Turkey has an economically intense relationship with its main trade partners. Therefore, as part of international economics literature, the J-curve hypothesis is analysed with panel data methods in this study. The long-term relationship among series being stationary in the same level but not $\mathrm{I}(0)$ is analysed via cointegration methods. Panel cointegration tests are studied under two topics based on whether they consist of interdivisional correlation. Depending on the homogeneity of these tests, the usage of appropriate test statistics is an important point.

Westerlund (2007) introduced four structural-based panel cointegration tests, and the null hypothesis for these tests is stated as no cointegration. The alternative hypothesis of this test's panel test statistics is that the whole panel is cointegrated, while the alternative 
hypothesis of group test statistics is that there is at least one cointegrated unit. Westerlund (2007) started from the equation below to generate test statistics.

$$
\begin{aligned}
& \Delta y_{i t}=\delta_{i}^{\prime} d_{t}+\alpha_{i}\left(y_{i t-1}-\beta_{i}^{\prime} x_{i t-1}\right)+\sum_{j=1}^{p_{i}} \alpha_{i j} \Delta y_{i t-j}+\sum_{j=0}^{p_{i}} \gamma_{i j} \Delta x_{i t-j}+e_{i t}, \\
& d_{t}=(1, t)^{\prime} \text { is a vector consisting of deterministic components and } \delta_{i}=\left(\delta_{1 i}, \delta_{2 i}\right)^{\prime}
\end{aligned}
$$

is a parameter of related deterministic components. The problem is to estimate the error correction parameter $\alpha_{i}$. One way to estimate related parameter is to assume that $\beta_{i}$ is known. In this case, $\alpha_{i}$ parameter is estimated by the OLS method. But Boswijk (1994) and Zivot (2000) indicate that tests based on a predetermined parameter are not similar and depend on nuisance parameters even if they are asymptotic. Separately multiplying parameters obtain an alternative approach to equation 1 with $y_{i t-1}$ and $\beta_{i}^{\prime} x_{i t-1}$.

$$
\Delta y_{i t}=\delta_{i}^{\prime} d_{t}+\alpha_{i} y_{i t-1}-\lambda_{i}^{\prime} x_{i t-1}+\sum_{j=1}^{p_{i}} \alpha_{i j} \Delta y_{i t-j}+\sum_{j=0}^{p_{i}} \gamma_{i j} \Delta x_{i t-j}+e_{i t},
$$

In this approach, $\alpha_{i}$ parameter is independent of the choice $\beta_{i}$. Since $\lambda_{i}$ it is unrestricted and cointegration vector is estimated indirectly from alternative hypothesis test based on $\alpha_{i}$ the parameter is asymptotic similar, and its distribution is not affected from nuisance parameters. That $\lambda_{i}$ parameter is not restricted can be seen from the $\lambda_{i}=-\alpha_{i} \beta_{i}$ equation. Two of the four test statistics depending on estimation of $\alpha_{i}$ the parameter in equation 2 via OLS method are panel (homogeneous) statistics, and the other two are group mean (heterogeneous) statistics. Group mean statistics are obtained in 3 steps:

Step 1: Equation 2 is estimated for each unit by the OLS method.

$$
\Delta y_{i t}=\hat{\delta}_{i}^{\prime} d_{t}+\hat{\alpha}_{i} y_{i t-1}-\hat{\lambda}_{i}^{\prime} x_{i t-1}+\sum_{j=1}^{p_{i}} \hat{\alpha}_{i j} \Delta y_{i t-j}+\sum_{j=0}^{p_{i}} \hat{\gamma}_{i j} \Delta x_{i t-j}+\hat{e}_{i t},
$$

Lag length $p_{i}$ changes from unit to unit, and lag length is chosen with the help of a data-dependent rule, information criteria, or constant function $T$. 
Step 2: $\alpha_{i}(1)=1-\sum_{j=1}^{p_{i}} \alpha_{i j}$ an equation is estimated. The most natural way to obtain this is to estimate $\alpha_{i}(1)$ by using $\tilde{\alpha}_{i}(1)=1-\sum_{j=1}^{p_{i}} \hat{\alpha}_{i j}$ an equation. $\tilde{\alpha}_{i}(1)$ based tests, especially when leg length $p_{i}$ is big, weakly perform in the small sample sizes due to uncertainty in estimating autoregressive parameters. The kernel estimator approach solves this problem. $\hat{\alpha}_{i}$, semi-parametric kernel estimator of $\alpha_{i}$, is obtained.

Step 3: Test statistics are generated.

$$
G_{\tau}=\frac{1}{N} \sum_{i=1}^{N} \frac{\hat{\alpha}_{i}}{S E\left(\hat{\alpha}_{i}\right)} G_{\alpha}=\frac{1}{N} \sum_{i=1}^{N} \frac{T \hat{\alpha}_{i}}{\hat{\alpha}_{i}(1)}
$$

$S E\left(\hat{\alpha}_{i}\right)$ is the standard error of $\hat{\alpha}_{i}$. Panel statistics are also calculated in 3 steps.

Step 1: Lag length $p_{i}$ is determined for each unit. Afterward, the regression models below are estimated.

$$
\begin{aligned}
& \Delta \tilde{y}_{i t}=\Delta y_{i t}-\hat{\delta}_{i}^{\prime} d_{t}-\hat{\lambda}_{i}^{\prime} x_{i t-1}-\sum_{j=1}^{p_{i}} \hat{\alpha}_{i j} \Delta y_{i t-j}-\sum_{j=0}^{p_{i}} \hat{\gamma}_{i j} \Delta x_{i t-j}, \\
& \tilde{y}_{i t-1}=y_{i t-1}-\hat{\delta}_{i}^{\prime} d_{t}-\hat{\lambda}_{i}^{\prime} x_{i t-1}-\sum_{j=1}^{p_{i}} \hat{\alpha}_{i j} \Delta y_{i t-j}-\sum_{j=0}^{p_{i}} \hat{\gamma}_{i j} \Delta x_{i t-j} .
\end{aligned}
$$

Step 2: Common error correction parameter $\alpha$ and standard deviation are estimated.

$$
\hat{\alpha}=\left(\sum_{i=1}^{N} \sum_{t=2}^{T} \tilde{y}_{i t-1}^{2}\right)^{-1} \sum_{i=1}^{N} \sum_{t=2}^{T} \frac{1}{\hat{\alpha}_{i}(1)} \tilde{y}_{i t-1} \Delta \tilde{y}_{i t}
$$

The standard error $\hat{\alpha}$ is calculated as below.

$$
\begin{aligned}
& S E(\hat{\alpha})=\left(\left(\hat{S}_{N}^{2}\right)^{-1} \sum_{i=1}^{N} \sum_{t=2}^{T} \tilde{y}_{i t-1}^{2}\right)^{-1 / 2} \\
& \hat{S}_{N}^{2}=\frac{1}{N} \sum_{i=1}^{N} \hat{S}_{i}^{2}
\end{aligned}
$$


$\hat{\sigma}_{i}$ is the standard deviation obtained from equation 2 . According to this, $\hat{S}_{i}$ it is calculated as $\hat{\sigma}_{i} / \hat{\alpha}_{i}(1)$.

Step 3: Panel statistics are calculated with the help of the equation below.

$$
P_{\tau}=\frac{\hat{\alpha}}{S E(\hat{\alpha})} P_{\alpha}=T \hat{\alpha}
$$

Westerlund (2007) proves via simulation that this test has higher power than the residual-based tests developed under the assumption that there is no correlation between units such as McCoskey and Kao (1998), Kao (1999), and Pedroni (1999, 2004) and shows good small sample size features having small disturbances. If variables are cointegrated, when one unit change in one variable happens, the movement of another variable in the long term is estimated with long-term estimation. Long-term estimators in panel data literature are determined according to whether they consider interdivisional correlation or homogeneous. In heterogeneous panels having interdivisional correlation, long-term estimation is made with The Panel Dynamic Ordinary Least Squares Mean Group (DOLSMG) method. This estimation method is derived from the equation below.

$$
y_{i t}=\mu_{i}+\beta_{i} x_{i t}+e_{i t} \quad i=1, . ., N \quad t=1, \ldots, T
$$

Indices in the constant and slope parameters indicate model changes based on units; the model is heterogeneous. $Z_{i t}$ expressed as $Z_{i t}=\left(x_{i t}, \bar{x}_{i}, \Delta x_{i t-k}, \ldots, \Delta x_{i t+k}\right)$ is the explanatory variables vector. According to this, DOLSMG estimation is made with the formula below.

$$
\begin{aligned}
& \hat{\beta}_{D O L S M G}=N^{-1}\left[\sum_{i=1}^{N}\left(\sum_{t=1}^{T}\left(Z_{i t} Z_{i t}^{\prime}\right)\right)^{-1}\right]\left(\sum_{t=1}^{T}\left(Z_{i t} \bar{Y}_{i t}\right)\right) \\
& \bar{Y}_{i t}=Y_{i t}-\bar{Y}_{i}
\end{aligned}
$$

DOLSMG estimator is calculated by taking the average of DOLS estimators calculated for each unit.

$$
\hat{\beta}_{D O L S M G}=N^{-1} \sum_{i=1}^{N} \hat{\beta}_{D O L S, i}
$$

Mark and Sul (1999) conducted the Monte Carlo simulation to evaluate the performance of the DOLS estimator. They applied Panel Dynamic OLS estimator and Weighted Panel Dynamic OLS estimator to the pooled data. They point out that the Weighted Panel Dynamic OLS estimator demonstrates small sample bias and recommend 
employing DOLS estimator. If long term relationship among variables is detected as a result of cointegration tests error correction model is utilized to analyse long and short-term relationships together. Panel error correction models are considered according to whether they consist of interdivisional correlation or are homogeneous. The dynamic common correlated effect (DCCE) estimator suggested by Chudik ve Peseran (2015) is a heterogeneous error correction model consisting of interdivisional correlation. The commonly correlated effect estimator suggested by Peseran (2006) is not robust in the existence of lagged dependent variables and weak exogenous independent variables. To solve these problems, a DCCE estimator is developed. In the DCCE estimator assuming y and $\mathrm{x}$ variables are stationary in their first differences (I(1)), cross-section means are added to the model to represent the unobserved factors. This model is shown below. Chudik and Pesaran (2015), in contrast with approaches of Bai (2009), Moon and Weidner (2010,2012), and Song (2013), emphasize that CCE (Common Correlated Effect) type estimators extended with an appropriate number of lags and cross-sectional means perform well even in dynamic models being of weak exogenous variables.

$$
\Delta y_{i t}=\alpha_{i}\left(y_{i t-1}-\lambda_{i}^{\prime} x_{i t-1}\right)+\sum_{j=1}^{p} \varphi_{j} \Delta y_{i t-j}+\sum_{j=0}^{p} \gamma_{j} x_{i t-j}+\sum_{j=1}^{p} \beta_{j} \Delta y_{t-j}+\sum_{j=1}^{p} \phi_{j} \Delta x_{t-j}+e_{i t}
$$

\section{Test Results}

Panel unit root tests are analysed under two generations as regards whether units consist of cross-sectional dependency. Tests of two generations differ by changes of autoregressive parameter, that is, by the homogeneity of the autoregressive parameter. Thus, it is required to test cross-sectional dependency and homogeneity by utilizing Dickey and Fuller's (1979) specification to determine the appropriate panel unit root test. Since panel data structure in this study is $\mathrm{T}>\mathrm{N}$ Breusch, and Pagan LM test whose asymptotic features is $\mathrm{T}>\mathrm{N}$ is used to test cross-sectional dependency. Swamy's $\mathrm{S}$ test is preferred to analyse for homogeneity.

Breusch Pagan LM and Swamy's S tests are applied to error terms obtained from the Dickey-Fuller Test equation with one lag represented in Equations 7 and 8 below.

$$
\begin{aligned}
& \Delta b o p_{i t}=\alpha_{0}+\alpha_{1} \operatorname{bop}_{i t-1}+\varphi \Delta b o p_{i t-1}+\varepsilon_{i t} \stackrel{O L S}{\rightarrow} \hat{\varepsilon}_{i t} \\
& \Delta e x c_{i t}=\beta_{0}+\beta_{1} e x c_{i t-1}+\theta \Delta e x c_{i t-1}+v_{i t} \stackrel{O L S}{\rightarrow} \hat{v}_{i t}
\end{aligned}
$$

Breusch Pagan LM test results show cross-sectional dependency for both series. Swamy's $S$ test results show that while the bop series exhibits heterogeneous features, the exc series shows homogeneous features. Thus, Pesaran's CADF test and Robust Breitung test are applied to the related series, respectively. Test results can be seen in Table 1. 
Table: 1

Panel Unit Root Test Results

\begin{tabular}{|c|c|c|c|}
\hline & Panel Unit Root Tests & Unit Root Test Statistics & p-value \\
\hline bop & Pesaran's CADF Test & -1.841 & 0.41 \\
\hline exc & Robust Breitung Test & -0.6276 & 0.26 \\
\hline
\end{tabular}

Panel unit root test results indicate that both series have unit root in the level. The first difference is taken for each series to determine the integration order, and the same panel unit root tests are applied. Results are shown in Table 2.

Table: 2

Panel Unit Root Test Results

\begin{tabular}{|c|c|c|c|}
\hline Variable & Panel Unit Root Test & Unit Root Test Statistics & Test Statistics Probability Value \\
\hline$\Delta($ bop $)$ & Pesaran CADF Test & -3.125 & 0.00 \\
\hline$\Delta(\mathrm{exc})$ & Robust Breitung Test & -4.026 & 0.00 \\
\hline
\end{tabular}

Unit root test results indicate that both series are stationary. So, a panel cointegration test could be applied to these series as they are stationary in their first difference. Panel cointegration tests are investigated under two generations according to whether error terms obtained from model estimation have a cross-sectional dependency. These tests become diversified regarding the existence of error correction-based and residual-based cointegration tests and at the same time regarding homogeneity and heterogeneity of units. As Monte Carlo simulations show that error correction model-based tests give better results, it is decided to use error correction-based cointegration tests. The convenient panel cointegration test utilizes Breusch and Pagan LM test and Swamy's S test in equation 11 below. Dummy variables are added to this model to consider the structural breaks, and CUSUM and CUSUM SQ tests are employed. Structural break dates are shown in Table 3.

Table: 3

Structural Breaks

\begin{tabular}{|c|c|}
\hline Countries & Time of Break \\
\hline China & 2009 \\
\hline Germany & 2003 \\
\hline Italy & 2013 \\
\hline Russian Federation & 1999 \\
\hline Turkey & 2001 \\
\hline United Kingdom & 2011 \\
\hline United States & 2013 \\
\hline
\end{tabular}

$\Delta b o p_{i t}=a_{0}+\alpha_{1} \Delta e x c_{i t}+\alpha_{2} \operatorname{bop}_{i t-1}+\alpha_{3} \operatorname{exc}_{i t-1}+\alpha_{4} \Delta b o p_{i t-1}+\alpha_{5} \Delta e x c_{i t-1}+\alpha_{6} D_{u m m y}+\varepsilon_{i t} \stackrel{o L S}{\rightarrow} \hat{\varepsilon}_{i t}$

Breusch Pagan LM test results show no cross-sectional dependency in the residuals obtained from the error correction model. At the same time, it is determined that residuals mentioned above have heterogenous features due to Swamy's $\mathrm{S}$ test. It is appropriate to consider the Heterogenous Test Statistics results of the Westerlund Panel Cointegration test. These results can be seen in Table 4 . 


\section{Table: 4}

Results of Westerlund Group Test Statistics

\begin{tabular}{|c|c|c|}
\hline Test Statistics Type & Test Statistics & Test Statistics Probability \\
\hline $\mathrm{G}_{\mathrm{t}}$ & -2.496 & 0.00 \\
\hline $\mathrm{G}_{\alpha}$ & -2.117 & 0.01 \\
\hline
\end{tabular}

Since the p-value is smaller than both Westerlund group test statistics $\mathrm{G}_{\mathrm{t}}$ and $\mathrm{G} \alpha$ null hypothesis stating nonexistence of cointegration is rejected, there is a cointegration relationship between the balance of payments and exchange rates, a long-term estimation can be applied after this test, long-term panel estimators are called first or second-generation regarding whether there is cross-sectional dependency and called homogenous or heterogeneous estimators based on homogeneity, to be able to find a long-term estimator, cross-sectional dependency and homogeneity tests should be applied. Among first and second-generation tests, the Breusch Pagan LM test and Swamy's S test are applied to the error term obtained from equation 12 . Test results reject the null hypothesis, which mentions no cross-sectional dependency.

$$
\text { bop }_{i t}=a_{0}+\alpha_{1} \operatorname{exc}_{i t}+\alpha_{2} \text { Dummy }_{i t}+\varepsilon_{i t} \stackrel{\text { OLS }}{\rightarrow} \hat{\varepsilon}_{i t}
$$

By using the same model, Swamy's S test is utilized to determine estimators among second-generation estimators. The null hypothesis expressing homogeneity is rejected. So, parameters are heterogeneous. Findings refer to the Dynamic Ordinary Least Squares Mean Group (DOLSMG) estimator. Dynamic Ordinary Least Squares could estimate variables by taking differences from cross-sectional means for units and whole panel by Pedroni's (2001) DOLSMG estimator, whose results are presented in Table 5.

Table: 5

\section{DOLSMG Test Results for Panel}

\begin{tabular}{|c|c|c|}
\hline Variables & Coefficient & t-Stat \\
\hline Exchange Rates & 0.0006299 & -1.846 \\
\hline Dummy & 0.03793 & 8.011 \\
\hline
\end{tabular}

Results do not show any meaningful relationship between exchange rates and balance of payments for $\% 5$ significance level. Even if the coefficient has the expected sign for the validity of the J-curve, it is not valid since the variable is not statistically significant for the whole panel. Dummy variable consisting of structural breaks is significant in the long term. Findings of the DOLS test are in the tables below. 
Table: 6

DOLS Test Results for Units

\begin{tabular}{|c|c|c|}
\hline \multicolumn{3}{|c|}{ 1. Variable: China } \\
\hline Variables & Coefficient & t-Stat \\
\hline Exchange Rates & 0.002231 & 1.472 \\
\hline Dummy & -0.1843 & -1.894 \\
\hline \multicolumn{3}{|c|}{ 2. Variable:Germany } \\
\hline Variables & Coefficient & $\mathrm{t}-$ Stat \\
\hline Exchange Rates & -0.004287 & -7.282 \\
\hline Dummy & 0.1339 & 14.33 \\
\hline \multicolumn{3}{|c|}{ 3. Variable:Italy } \\
\hline Variables & Coefficient & t-Stat \\
\hline Exchange Rates & 0.002872 & 0.7648 \\
\hline Dummy & 0.2285 & 6.247 \\
\hline \multicolumn{3}{|c|}{ 4. Variable:Russian Federation } \\
\hline Variables & Coefficient & t-Stat \\
\hline Exchange Rates & 0.0005486 & 0.3098 \\
\hline Dummy & 0.4417 & 4.338 \\
\hline \multicolumn{3}{|c|}{ 5. Variable:Turkey } \\
\hline Variables & Coefficient & t-Stat \\
\hline Exchange Rates & 0.002482 & 0.8074 \\
\hline Dummy & 0.06817 & 0.6916 \\
\hline \multicolumn{3}{|c|}{ 6. Variable:United Kingdom } \\
\hline Variables & Coefficient & t-Stat \\
\hline Exchange Rates & 0.003609 & 0.967 \\
\hline Dummy & -0.3098 & -1.28 \\
\hline \multicolumn{3}{|c|}{ 7. Variable:United States } \\
\hline Variables & Coefficient & $\mathrm{t}-\mathrm{Stat}$ \\
\hline Exchange Rates & -0.003045 & -1.923 \\
\hline Dummy & -0.1127 & -1.24 \\
\hline
\end{tabular}

Statistical results of individual countries, except Germany, for long-term parameters, are insignificant, but although Germany's test results are significant coefficient sign is negative. Exchange rates do not have any effect on the balance of payments for China. Jcurve is not valid. In the same way, the structural break in 2009 does not influence the longterm balance of payments. When considering test results for Germany, it is shown from Table 6 exchange rates impact the balance of payments in a negative direction. That is, an increase in import becomes bigger than the increase in export as exchange rates rise. Thus, the J-curve approach is not valid for Germany but the structural break happening in 2003 affects the balance of payments in the long term. Exchange rates do not affect the balance of payments for Italy, Russia, Turkey, and the UK. So, J-curve is not valid. A structural break in 2013 for Italy affects the balance of payments in the long term. For Russia, a structural break in 1999 had a long-term effect on the balance of payments. A structural break in 2001 for UK and Turkey does not affect the balance of payments in the long term. For the USA, exchange rates have an impact on the balance of payments in a negative direction. Thus, the J-curve approach is not valid, but the structural break in 2013 does not affect the balance of payments in the long term.

As panel and individual country, J-curve is not valid according to findings. Panel error correction estimation is employed to check the short-term results and control if the correction mechanism works properly. There are two generations of panel error correction models depending on cross-sectional dependency, and these models vary among them as homogenous and heterogenous panel error correction models. Cross-sectional dependency and homogeneity tests are applied on error obtained from equation 13. 


$$
\Delta b o p_{i t}=a_{0}+\alpha_{1} \Delta e x c_{i t}+\alpha_{2} \text { bop }_{i t-1}+\alpha_{3} \operatorname{exc}_{i t-1}+\alpha_{4} \Delta b o p_{i t-1}+\alpha_{5} \Delta e x c_{i t-1}+\alpha_{6} D u m m y_{i t}+\varepsilon_{i t} \stackrel{o L S}{\rightarrow} \hat{\varepsilon}_{i t}
$$

Since there is no cross-sectional dependency and residuals show heterogenous features second-generation heterogenous panel error correction model is preferred. Among these tests, as Common Correlated Effect (CCE) and Augmented Mean Group (AMG) estimators are not consistent under the assumption of weak exogeneity Dynamic Common Correlated Effect (DCCE) estimator is preferred. Results are shown in Table 7 below. From the whole panel, exchange rates do not affect the balance of payment in the short term. Even though the coefficient has the expected sign, it is insignificant. So, J-curve is not valid.

\section{Table: 7}

\section{DCCE Test Results for Panel}

\begin{tabular}{|c|c|c|}
\hline Variables & Coefficient & $\mathrm{p}$-value \\
\hline$\Delta(\mathrm{exc})$ & -0.000774 & 0.688 \\
\hline
\end{tabular}

Table: 8

\section{DCCE Test Results for Units}

\begin{tabular}{|c|c|c|}
\hline \multicolumn{3}{|c|}{ 1. Unit - China } \\
\hline Variables & Coefficient & $\mathrm{p}$-value \\
\hline$\Delta(\mathrm{exc})$ & 0.006907 & 0.665 \\
\hline \multicolumn{3}{|c|}{ 2. Unit - Germany } \\
\hline Variables & Coefficient & p-value \\
\hline$\Delta(\mathrm{exc})$ & 0.000948 & 0.000 \\
\hline \multicolumn{3}{|c|}{ 3. Unit - Italy } \\
\hline Variables & Coefficient & p-value \\
\hline$\Delta(\mathrm{exc})$ & -0.006646 & 0.208 \\
\hline \multicolumn{3}{|c|}{ 4. Unit - Russian Federation } \\
\hline Variables & Coefficient & $\mathrm{p}$-value \\
\hline$\Delta(\mathrm{exc})$ & -0.00012 & 0.000 \\
\hline \multicolumn{3}{|c|}{ 5. Unit - Turkey } \\
\hline Variables & Coefficient & p-value \\
\hline$\Delta(\mathrm{exc})$ & -0.007437 & 0.764 \\
\hline \multicolumn{3}{|c|}{ 6. Unit - United Kingdom } \\
\hline Variables & Coefficient & $\mathrm{p}$-value \\
\hline$\Delta(\mathrm{exc})$ & 0.002858 & 0.334 \\
\hline \multicolumn{3}{|c|}{ 7. Unit - United States } \\
\hline Variables & Coefficient & $\mathrm{p}$-value \\
\hline$\Delta(\mathrm{exc})$ & -0.001932 & 0.070 \\
\hline
\end{tabular}

In the short term, test results are significant for Germany and Russia, but they are insignificant for other countries individually. Exchange rates do not affect the balance of payments in China, but it affects the balance of payments in Germany. However, the coefficient sign is the opposite; thus, J-curve is not valid in Germany. In the long run, exchange rates affect the balance of payments in a negative direction for Germany. So, Jcurve is moving in the opposite of the expected direction.

In the short term, exchange rates do not affect the balance of payments in Italy. In Russia, exchange rates have a negative effect on the balance of payments. This is a condition for the validity of the J-curve, but since exchange rates do not impact the balance of payments, in the long run, there is not enough evidence for the validity of the J-curve. In the short term, exchange rates do not affect the balance of payments in Turkey and the UK. For the USA, exchange rates affect the balance of payments in the $\% 90$ confidence level. 
Gözen, M.Ç. \& F.C. Bostanc1 (2021), "Validity of J-Curve for Turkey and Its Main External

Trade Partners: An Application of a Panel Data Approach", Sosyoekonomi, 29(50), 149-168.

\section{Conclusion}

Numerous studies have sought the validity of J-curve in the past few decades. However, conclusive evidence from the studies has not been reached. The short-run and long-run impact of currency depreciation on Turkey's trade balance are argued with the help of the J-curve phenomenon in the literature, suggesting that trade balance after depreciation deteriorates in the short run but improves in the long run. Previous studies searching for the existence of J-curve for Turkey and other countries reached mixed results. They mainly employ time series methods, not considering the impacts of main trading partners' dynamics on the existence of J-curve. Rose and Yellen (1989), Moffett (1989), Backus et al. (1994), Demirden and Pastine (1995), Hsing and Sergi (2010), and Bahmani-Oskooee and Wang (2006) prefer to employ time series methods, and their findings do not support the existence of J-curve.

On the other hand, Bahmani-Oskooee et al. (2018), Nusair (2017), Bahmani-Oskooee and Fariditavana (2016), Bahmani-Oskooee and Fariditavana (2015), and Bahmani-Oskooee and Kutan (2009) use time series methods, but empirical results from these studies support the validity of J-curve. Panel data methods utilized in this study allow us to include the impacts of the dynamics of six main trading partners on the existence of J-curve for Turkey, which makes this study different from the previous studies. Thus, J-curve is tested by using an annual panel dataset covering the period 1995-2018.

For each country, findings from DOLS estimation results do not provide any evidence to support the validity of J-curve since $t$ statistics are insignificant in all countries, excluding Germany being of negative coefficient sign denoting that J-curve is invalid in the long run. Test results analysing the short run show whole panel is statistically insignificant. Global economic system makes countries dependent on imports for consumption and production needs. Most of the developing and developed countries become dependent on imports, particularly energy, for export. Moreover, rising exchange rates increase the cost of entry of high value-added advanced technology and capital goods into the country. In addition to these reasons, opportunities for developing countries with chronicle balance of payment deficit problems to compete with developed countries and their reflexes to make different productions to respond to changing foreign demands are limited. Because of these reasons, the devaluation of domestic currencies does not generate the desired results in the short- and long-run.

Turkey is also dependent on imports, and Turkey's largest import item is energy. Thus, devaluation makes Euro and US Dollar more expensive relative to the Turkish Lira. This, in turn, increases the cost of export products and makes them expensive. In the short run, $t$ statistics are significant for Germany and Russia, but Germany has an unexpected sign. J-curve is not valid since it does not have an expected coefficient sign in the long and short run. Germany was the third-largest exporter and importer country in 2018. Devaluation is expected to have a negative impact on Germany's balance of payments. Still, Germany's balance of payments recovers in the short term and worsens in the long run, contrary to 
expectations. When there is a devaluation in Euro, that means devaluation happens in all Euro-Area countries. Germany's import and export partner shares in Euro-Area are about $\% 36$ and \%39 respectively. A large part of Germany's trade is with Euro-Area countries, and this might be one of the reasons for the invalidity of J-Curve analysis for Germany. Although this is the topic for another research, it might be why the competition power of Euro Area countries in prices could be higher than Germany.

Even though Russia has expected sign in the short run, its t-statistics is insignificant in the long run. Thus, J-curve does not exist in Russia. For Turkey, these findings are in line with the findings of Rose (1990), Yazic1 and Klasra (2010), Akkaya (2018), Y1lmaz et al. (2017), Hepaktan (2016), Halicioglu (2008) and Akbostanc1 (2004) but inconsistent with the findings of Brada et al. (1997), Kemeç and Kösekahyaoğlu (2015) and Bal and Demiral (2012). Time-series methods are employed for most of the J-curve literature for Turkey. Using panel data methods in this literature could provide better reliable results and enable conclusive evidence.

\section{References}

Akbostanci, E. (2004), "Dynamics of The Trade Balance the Turkish J-curve", Emerging Markets Finance and Trade, 40(5), 57-73.

Akkaya, O. (2018), “Türkiye ve Türkiye'nin Dış Ticaret Partnerleri Arasındaki İki Yanlı J eğrisi: 1996-2006 Dönemi İncelemesi”, Finans Ekonomi ve Sosyal Araştırmalar Dergisi (FESA), 3(1), 328-338.

Ali, S.Z. \& S. Anwar (2018), “Anticipated versus Unanticipated Terms of Trade Shocks and the JCurve Phenomenon”, Journal of International Money and Finance, 81, 1-19.

Backus, D.K. \& P.J. Kehoe \& F.E. Kydland (1994), "Dynamics of Trade Balance and the Terms of Trade: the J-Curve?", American Economic Review, 84(1), 84-103.

Bahmani-Oskooee, M. \& A.M. Kutan (2009), "The J-curve in the Emerging Economies of Eastern Europe", Applied Economics, 41(20), 2523-2532.

Bahmani-Oskooee, M. \& H. Fariditavana (2015), "Nonlinear ARDL Approach, Asymmetric Effects and the J-curve", Journal of Economic Studies, 42(3), 9-530.

Bahmani-Oskooee, M. \& H. Fariditavana (2016), "Nonlinear ARDL Approach and the J-curve Phenomenon", Open Economies Review, 27(1), 51-70.

Bahmani-Oskooee, M. \& H. Masoomeh (2012), “German-US Commodity Trade: Is There a J-curve Effect?”, Applied Economics Quarterly, 58(4), 327-353.

Bahmani-Oskooee, M. \& N. Bose \& Y. Zhang (2018), "Asymmetric Cointegration, Nonlinear ARDL, and the J-curve: a Bilateral Analysis of China and its 21 Trading Partners", Emerging Markets Finance and Trade, 54(13), 3131-3151.

Bai, J. (2009), "Panel Data Models with Interactive Fixed Effects", Econometrica, 77(4), 1229-1279.

Bal, H. \& M. Demiral (2012), "Reel Döviz Kuru ve Ticaret Dengesi: Türkiye'nin Almanya ile Ticareti Örneği (2002.01-2012.09)", Ç.Ü. İİ.B.F. Dergisi, 16(2),45-64.

Brada, J.C. \& A.M. Kutan \& S. Zhou (1997), "The Exchange Rate and the Balance of Trade: The Turkish Experience", The Journal of Development Studies, 33(5), 675-692. 
Breitung, J. \& S. Das (2005), "Panel Unit Root Tests Under Cross-Sectional Dependence”, Statistica Neerlandica, 59(4), 414-433.

Breusch, T.S. \& A.R. Pagan (1980), "The Lagrange Multiplier Test and its Applications to Model Specification in Econometrics", The Review of Economic Studies, 47(1), 239-253.

Chudik, A. \& M.H. Pesaran (2015), "Common Correlated Effects Estimation of Heterogeneous Dynamic Panel Data Models with Weakly Exogenous Regressors", Journal of Econometrics, 188(2), 393-420.

Demirden, T. \& I. Pastine (1995), "Flexible Exchange Rates and the J-curve: An Alternative Approach", Economics Letters, 48, 373-377.

Dickey, D.A. \& W.A. Fuller (1979), "Distribution of the Estimators for Autoregressive Time Series with a Unit Root", Journal of the American Statistical Association, 74(366a), 427-431.

Elmas, Y. \& Y. Elmas (2019), "J Eğrisi Etkisinin Eşbütünleşme, Nedensellik ve Wilcoxon İşaret Sıra Testi ile Değerlendirilmesi: Bandırma İlçesi Örneği”, 2. Uluslararası Bandırma ve Çevresi Sempozyumu, 17-19 Eylül 2019, Bandırma, 295-312.

Halicioglu, F. (2008), “The Bilateral J-curve: Turkey versus her 13 Trading Partner”, Journal of Asian Economics, 19(3), 236-243.

Hepaktan, C.E. (2016), "Yapısal Kırılmalar Altında Türkiye’de J Eğrisinin Analizi”, Celal Bayar Üniversitesi Sosyal Bilimler Dergisi, 14(4), 75-102.

Hsing, Y. \& B.S. Sergi (2010), "Test of the Bilateral Trade J-curve between the USA and Australia, Canada, New Zealand and The UK", International Journal of Trade and Global Markets, 3(2), 189-198.

Kao, C. (1999), "Spurious Regression and Residual-based Tests for Cointegration in Panel Data", Journal of Econometrics, 90(1), 1-44.

Kösekahyaoğlu, L. \& A. Kemeç (2015), “J Eğrisi Analizi ve Türkiye Üzerine Bir Uygulama” Uluslararasi İktisadi ve İdari Bilimler Dergisi, 1(2), 1-29.

Kösekahyaoğlu, L. \& İ. Karataşl1 (2018), “Türkiye - AB Dış Ticaretinde J Eğrisi Etkisi : 1994- 2016 Dönemi Üzerine Ampirik Bir İnceleme”, SDÜ İIBF Dergisi, 23(Özel Say1), 831-844.

Lerner, A.P. (1944), The Economics of Control: Principles of Welfare Economics, The Macmillan Company, New York.

Magee, S.P. (1973), “Currency Contracts, Pass-through, and Devaluation”, Brookings Papers of Economic Activity, 1973(1), 303-323.

Mark, N. \& D. Sul (1999), “A Computationally Simple Cointegration Vector Estimator for Panel Data", Ohio State University Manuscript, <https://www.researchgate.net/publication/2312524_A_Computationally_Simple_Cointe gration_Vector_Estimator_for_Panel_Data>, 01.05.2020.

Marshall, A. (1923), Money, Credit and Commerce, Macmillan, London.

McCoskey, S. \& C. Kao (1998), "A Residual-based Test of the Null of Cointegration in Panel Data”, Econometric Reviews, 17(1), 57-84.

Moffett, M.H. (1989), "The J-Curve Revisited: An Empirical Examination for the United States", Journal of International Maney and Finance, 8(3), 425-444.

Moon, H.R. \& M. Weidner (2010), "Dynamic Linear Panel Data Regression Models with Interactive Fixed Effects", Working Paper, University of Southern California. 
Moon, H.R. \& M. Weidner (2012), "Linear Regression for Panel with Unknown Number of Factors as Interactive Fixed Effects", Working Paper, University of Southern California.

Nusair, S.A. (2017), "The J-curve Phenomenon in European Transition Economies: a Nonlinear ARDL Approach", International Review of Applied Economics, 31(1), 1-27.

Pedroni, P. (1999), "Critical Values for Cointegration Tests in Heterogeneous Panels with Multiple Regressors", Oxford Bulletin of Economics and Statistics, 61(1), 653-670.

Pedroni, P. (2001), "Purchasing Power Parity tests in Cointegrated Panels", Review of Economics and Statistics, 83(4), 727-731.

Pedroni, P. (2004), "Panel Cointegration: Asymptotic and Finite Sample Properties of Pooled Time Series Tests with an Application to the PPP Hypothesis", Econometric Theory, 20(3), 597-625.

Pesaran, M.H. (2007), "A Simple Panel Unit Root Test in the Presence of Cross-section Dependence", Journal of Applied Econometrics, 22(2), 265-312.

Rose, A.K. \& J.L. Yellen (1989), "Is There a J-Curve", Journal of Monetary Economics, 24, 53-68.

Rose, A.K. (1990), "Exchange Rates and Trade Balance: Some Evidence from Developing Countries", Economic Letters, 34(3), 271-275.

Salmon, P. (2003), Decentralization and Supranationalty: The Case of the European Union, <http://www.imf.org/external/pubs/fiscal/salmon.pdf>, 02.10.2003.

Song, M. (2013), “Asymptotic Theory for Dynamic Heterogeneous Panels with Cross-sectional Dependence and its Applications", Working Paper.

Swamy, P.A.V.B. (1970), "Efficient Inference in a Random Coefficient Regression Model", Econometrica: Journal of the Econometric Society, 38(2), 311-323.

Wang, C. \& C.A. Lin \& C. Yang (2012), "Short-run and Long-run Effects of Exchange Rate Change on Trade Balance: Evidence from China and its Trading Partners", Japan and the World Economy, 24(4), 266-273.

Westerlund, J. (2007), "Testing for Error Correction in Panel Data", Oxford Bulletin of Economics and Statistics, 69(6), 709-748.

Yazici, M. \& M.A. Klasra (2010), "Import Content of Exports and J-curve Effect", Applied Economics, 42(6), 769-776.

Yılmaz, S. \& İ. Özaytürk \& G. Oransay (2017), "Testing the Hypothesis of J-curve for Turkish Economy”, Chinese Business Review, 16(9), 419-428. 